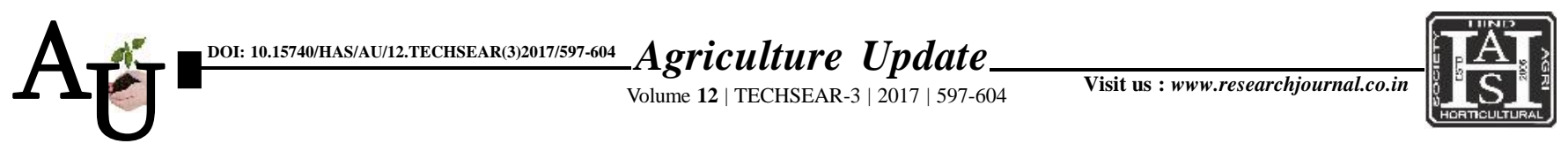

— e ISSN-0976-6847

\title{
Research Article: Influence of different spraying dates on pod borer complex of pigeonpea
}

\section{S.V. SHINDE, D.R. KADAM, M.M. SONKAMBLE AND B.S. KADAM}

Article Chronicle :

Received :

10.07.2017;

Accepted :

25.07.2017

KeY Words:

Spraying dates, Pod borer complex,

Helicoverpa

armigera, Erias

atomosa

Author for correspondence :

\section{S.V.SHINDE}

Department of

Agricultural

Entomology, Vasantrao

Naik Marathwada Krishi

Vidyapeeth, PARBHANI

(M.S.) INDIA

See end of the article for

authors' affiliations
SUMMARY : A experiment was conducted at Experimental Research Farm Department of Agril. Entomology, Vasantrao Naik Marathwada Krishi Vidyapeeth, Parbhani, during the Kharif 2016 to study effect of different spraying dates on management of pod borer complex of pigeonpea in three different cultivars in split plot design. Two consecutive sprays of emamectin benzoate 5\% SG @ $4.4 \mathrm{gm} / 10$ lit. water followed by flubendiamide 39.3\% SC @ $3.9 \mathrm{ml} / 10$ lit. water at 15 days interval were taken at various crop growth stages. Three cultivars of pigeonpea viz., BDN-711 (early), BSMR-716 (mid late), BSMR-736 (late) were observed under field condition for their response to pod borer complex. The results revealed that in BDN-711 spraying at 50\% bud initiation stage was superior treatment whereas in BSMR-716 crop sprayed at $10 \%$ flowering stage recorded minimum pest incidence and produced higher yield. In the cultivar BSMR-736, crop sprayed at flower initiation stage recorded minimum incidence of $H$. armigera and maximum yield. In above three cultivars, the incidence of $E$. atomosa was minimum, when the crop was sprayed at pod formation stage.

How to cite this article : Shinde, S.V., Kadam, D.R., Sonkamble, M.M. and Kadam, B.S. (2017). Influence of different spraying dates on pod borer complex of pigeonpea. Agric. Update, 12(TECHSEAR-3) : 597-604; DOI: 10.15740/HAS/AU/12.TECHSEAR(3)2017/597-604. 